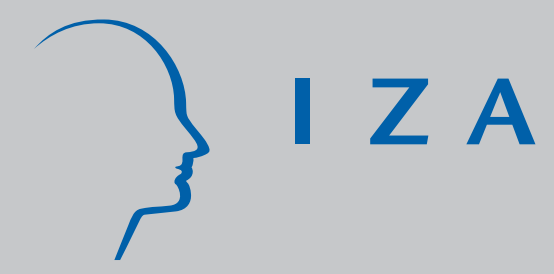

IZA DP No. 1593

Piecework versus Timework in British Wartime Engineering

Robert A. Hart

May 2005 


\title{
Piecework versus Timework in British Wartime Engineering
}

\author{
Robert A. Hart \\ University of Stirling \\ and IZA Bonn
}

\section{Discussion Paper No. 1593 \\ May 2005}

\author{
IZA \\ P.O. Box 7240 \\ 53072 Bonn \\ Germany \\ Phone: +49-228-3894-0 \\ Fax: +49-228-3894-180 \\ Email: iza@iza.org
}

\begin{abstract}
Any opinions expressed here are those of the author(s) and not those of the institute. Research disseminated by IZA may include views on policy, but the institute itself takes no institutional policy positions.

The Institute for the Study of Labor (IZA) in Bonn is a local and virtual international research center and a place of communication between science, politics and business. IZA is an independent nonprofit company supported by Deutsche Post World Net. The center is associated with the University of Bonn and offers a stimulating research environment through its research networks, research support, and visitors and doctoral programs. IZA engages in (i) original and internationally competitive research in all fields of labor economics, (ii) development of policy concepts, and (iii) dissemination of research results and concepts to the interested public.
\end{abstract}

IZA Discussion Papers often represent preliminary work and are circulated to encourage discussion. Citation of such a paper should account for its provisional character. A revised version may be available directly from the author. 


\begin{abstract}

\section{Piecework versus Timework in British Wartime Engineering*}

The British engineering industry experienced extreme production and employment pressures during the rearmament period that preceded the Second World War and in the early war years. Did it react by placing a greater emphasis on incentive-compatible payment methods? This paper examines the relative employment and wage effects on pieceworkers and timeworkers. Empirical work is based on detailed firm-level payroll data produced by the Engineering Employers Federation covering the period 1935 to 1942. The paper investigates the effects of war on piecework and timework in relation to (a) labour market arguments concerning substitution between payment methods, (b) piece rate/time rate adjustments to changes in product demand, (c) relative changes in employment and hours, and (d) relative changes in hourly and weekly pay.
\end{abstract}

JEL Classification: J31, J33, N34, N44

Keywords: $\quad$ piecework, timework, British engineering, World War II

Corresponding author:

Robert A Hart

Department of Economics

University of Stirling

Stirling FK9 4LA

Scotland

UK

Email: r.a.hart@stir.ac.uk

\footnotetext{
* Data collection and empirical work was funded by ESRC Grant RES-000-22-0491. I am grateful to the Engineering Employers Federation for allowing access to their payroll statistics and to Warwick University Modern Record Centre and Glasgow University Archive Services for their help in assembling the material. Adele Redhead was especially helpful at Glasgow. Thanks also to Andrew Currall, Lucy Burrows and Elva McLean for work on transcribing data from EEF archives to computer spreadsheets. Elizabeth Roberts provided excellent research assistance.
} 


\section{Introduction}

Empirical work based on specific case studies has found quite sizeable productivity gains when comparable workers operate under a piece rate rather than a time rate pay system (Lazear, 2000; Paarsch and Shearer, 2000). It is also well established that pieceworkers enjoy higher earnings relative to timeworkers (see also Pencavel, 1977 and Seiler, 1984). Yet piecework is by no means the dominant payments system in national labour markets. Piecework tends to have a comparative advantage where it is relatively inexpensive to measure and monitor individual contributions to output and to operate quality control systems. Unsurprisingly, therefore, there is a relatively high incidence among manual workers. Pencavel (1977) shows that between 1947 and 1961 at least 40 percent of British male manual workers in metal manufacture, shipbuilding and marine engineering, vehicles, and other metals and engineering worked on a payments-by-results basis. Concentrating on manual workers in British engineering, this paper examines the impact of the Second World War on the relative incidence, hours of work and pay of pieceworkers and timeworkers. This is an especially interesting period because it produced acute pressures on the industry to switch towards incentive-based payments systems.

Given relatively stable macroeconomic growth over a prolonged period, we might expect that the incidences of piecework and timework would not vary greatly. Product type, production methodology, labour quality and work organisation may combine to make piecework the more cost effective remuneration system. Other combinations may favour timework. Trend changes towards one system or the other would be expected to follow major, relatively long-term, innovations in product development, technological 
know-how, employee training, and organisational structure. ${ }^{1}$ A comparative advantage to studying wage systems in war-affected years is that major changes took place over a short period of time. Extreme demand for war-related engineering products, exacerbated by acute skill shortages, gave rise to a set of economic circumstances that forced many engineering companies to change radically their worker skill inputs and methods of production. The issue of piecework versus timework featured prominently within this reorganisation.

Section 2 outlines briefly the growth of the engineering industry in the run-up to war and during the war years. Labour market arguments concerning the relative employment and pay of pieceworkers and timeworkers during this important episode of economic history are presented in Section 3. Sections 4 to 7 report related empirical findings based on a unique data set produced by the Engineering Employers Federation (EEF). Wages and hours statistics were compiled from the payroll records of affiliated member firms. The Federation's membership was highly representative of the industry as a whole. In 1940, there were over 2000 engineering firms in the EEF, employing about 1 million workers and covering all sections of the industry (see Marsh, 1965, p.48). Payroll statistics of member firms were systematically collated largely for the purposes of providing employers with critical information during national level bargaining with

\footnotetext{
${ }^{1}$ If we take the period from the end of the Second World War to the late 1950s/early 1960s as a relatively stable period, Pencavel (1977) shows modest changes in the incidence of payments-by-results among U.S. production workers and among British female manual workers. By contrast, there was significant growth in the incidence of payments-by-results among British male manual workers; for example, the percentage of manual workers in metal manufacture grew from 50 percent to 62 percent between 1947 and 1961. However, in 'other metals and engineering' the classification nearest to the data studied here, the percentage rose very slightly from 44 to 45 percent. Pencavel also reports evidence that no discernible new British patterns of piecework incidence arose between 1961 and 1967.
} 
engineering unions. Data cover engineering occupations, engineering sections and geographical EEF districts between 1935 and 1942. All data are provided separately for pieceworkers and timeworkers. I concentrate on male workers. Section 4 examines the relative sensitivity of piece rates and time rates to demand changes during the run-up to war. Section 5 reports on changes in the incidence of pieceworking over the period and on the weekly hours of workers under the two payments regimes. Section 6 analyses piecework/ timework earnings differentials, embracing both wage rates and hours. Section 7 highlights the effects of the exceptional labour market pressures on piece rates in Coventry relative to other engineering districts. Main findings are summarised in Section 8.

\section{Engineering growth between 1935 and 1942}

Starting in 1935, a series of rearmament programmes acted as catalysts for major expansions of Britain’s engineering sector (Inman, 1957, Chapter 2). Annual percentage increases in real production of 17, 15 and 10 percent occurred in 1935, 1936, and 1937, respectively. Figure 1 shows production expansion in the run-up to war was significantly higher in engineering than either in manufacturing as a whole or in other major one-digit industries. During the war years there was a considerable growth of employment in engineering and closely related industries. Between 1938 and its peak in 1943, employment in engineering and allied industries (metals, vehicles and shipbuilding) grew by 80 percent (from 2590 thousand to 4659 thousand employees). Figure 2 shows that steep employment increases in this group of industries together with the armed forces contrasted markedly with flat or declining employment elsewhere. Growth in product demand and employment was by no means evenly spread across engineering sections and 
geographical engineering districts, however. For example, pressure was especially intense in aircraft manufacture and in associated local labour markets such is the Coventry area.

\section{Figures 1 and 2 here}

Several well known sources of increased labour input are documented in the Ministry of Labour and National Service (1947) and Inman (1957). Employment growth derived from engineering workers returning to the industry following the Great Depression as well as from workers who were attracted from other industries by relatively high wages. As engineering firms in key locations faced plant, capacity, materials and management constraints, there was an increased tendency to employ labour from outside firms through sub-contracting. The latter was especially important in aircraft manufacture (Inman, 1957, pp.24/5). On firms’ intensive margins, average weekly hours per worker grew dramatically during war-affected years (see Section 5).

As the pressures of war preparation and execution intensified, production methods were radically revised. Broad work areas traditionally covered by skilled workers were broken down into component job tasks. Semi-skilled workers were trained over relatively short training periods in order to perform some of these tasks. Other tasks were identified as suitable for semi-skilled work per se. The development and application of automatic and semi-automatic machines helped greatly in this latter respect. This work re-classification was universally referred to as labour dilution (see Parker, 1981). ${ }^{2}$ In the

\footnotetext{
${ }^{2}$ Dilution is not especially a well-chosen term. It is meant to convey the fact that a coherent set of job tasks defined under broadly-based skilled trades increasingly ceased to be performed by single individuals. Instead, they were broken down (or diluted) into sub-sets of tasks and shared among more narrowly trained skilled workers and semi-skilled workers. But in important respects this process provided for better
} 
early war years dilution involved a significant expansion of female jobs: females accounted for 10 percent of total engineering employment in 1939, a figure that rose to 35 percent by 1943. From 1940, female engineering workers were classified into two groups: ‘women doing men’s work' and 'women doing women and boys work'. The former group undertook a 32 week training period that allowed them to undertake skilled and semi-skilled job tasks in vital wartime sectors such as aircraft manufacture and heavy general engineering (Hart, 2004).

Apart from increasing the stock and utilisation of labour input, there was another potentially important method of meeting output requirements. This was to induce greater productive effort by substituting towards incentive-based pay. This is the focus of attention here. Throughout the 1920s and 1930s, both piecework and timework comprised important components of work activity throughout most sections of the engineering industry (Knowles and Hill, 1954). Piecework represented a high proportion of total labour input in sections like aircraft manufacture, electrical engineering and heavy general engineering. Timework was relatively more prevalent in marine engineering, sheet metal working and light general engineering. The critical questions in this paper concern the marginal effects of war on the relative workforce sizes, working time and pay of the two groups.

\section{Piecework versus timework under the pressure of war demand}

This section discusses a number of war-related issues that would be expected to influence the relative incidence and remuneration of piecework and timework. At the end

matches between skill and work requirements. For example, increasingly scarce highly skilled workers could now concentrate their work effort purely on tasks that demanded the most experience and know-how. 
of the section, the key points are summarised and form the basis of the subsequent empirical investigation.

At the outset, it is useful to distinguish between the weekly wage earnings of timeworkers and pieceworkers. To simplify, overtime premium payments are ignored. Wage earnings of a timeworker, $y^{T}$, simply consists of an hourly wage rate, $w^{T}$, multiplied by the length of weekly hours, $h^{T}$ : that is

(1) $y^{T}=w^{T} h^{T}$

By contrast, weekly earnings of a pieceworker are dependent on weekly output. In principle, a piece rate represents payment for the time taken by a 'typical' worker to complete a specified job task by applying ‘normal' hourly effort. Piece rates could be set independently by 'time and motion' engineering experts although, as we will see, this was not the only infuence on rates setting. Following Pencavel (1977), the weekly earnings of a piecworker, $y^{P}$, is represented by applying an index, dependent on hours and effort, to the piece rate. This is expressed

(2) $y^{P}=p \Phi\left[h^{P}, e\right]$

where $p$ is the piece rate, $\Phi$ is an incentive payments index predicated on a pieceworker's weekly hours, $h^{P}$, and hourly effort, $e$.

(a) Pay responsiveness to market conditions

Piecework offered British engineering employers the potential to achieve relatively high wage flexibly in the face of exceptional wartime demand and supply dynamics. This was especially attractive at a time of extreme labour scarcity in core 
engineering districts and sections where it became imperative both to prevent quits among the existing workforce and to attract new recruits from elsewhere. While there was scope for firm-level time rate adjustments, the levels and occupational distributions of time rates (i.e. $w^{T}$ in (1)) were subject to considerable national-level influence. Essentially, all EEF annual time rates were based on national bargains struck with respect to just two occupations. ${ }^{3}$ Pieceworkers' earnings were settled primarily by companylevel bargaining (Knowles and Hill, 1954). There was some attempt at Federation-level to established a percentage relationship between the basic time rate and the least that a pieceworker of average ability could expect to earn. ${ }^{4}$ Predominantly, however, piecework remuneration were settled at local level, with a great complexity of payments within and between engineering sections due to (i) the need to set a vast number of piecework prices and related job task execution times, (ii) wide variations in the methods of arriving at agreed piece rates and (iii) a lack of experience of how to set piece rates in wartime product demand conditions

Why would we expect more flexible market responses among pieceworkers earnings? First, it was much harder to control and monitor piece rates than time rates. “Owing to the immense number of different processes and operations in so heterogeneous an industry, as well as to the rapidity of technical developments, any general control over piece-work earnings can be no more than minimal” (Knowles and Hill, 1954). Second,

\footnotetext{
${ }^{3}$ National rates were negotiated in respect of fitters and labourers. From 1922, nationally agreed rates applied uniformally throughout the Federation in Britain. Rates for other occupations were then related to one or other of these two occupational groups, again involving large elements of national agreements.

${ }^{4}$ This was set at 25 percent between June 1931 and March 1943 and 27.5 percent until November 1950. A further national level agreement involving both payment methods was that both timeworkers and pieceworkers received a so-called National Bonus throughout this period. Pieceworkers received a lower Bonus than timeworkers.
} 
wartime deskilling was achieved by job task compartmentalisation and simplification.

This improved employers' abilities to monitor work performance and allowed greater control of effort levels to meet prevailing demand conditions. Through (2) this directly impacted on pieceworkers' earnings. Third, as argued by Knowles and Robertson (1951a) unfamiliarity with the special demands of war supply prevented accurate piece rate pricing. This offered considerable scope for gearing piece rates towards alleviating acute labour market pressures - especially attracting and retaining scarce labour - rather than reflecting systematic engineering-based 'time and motion' price setting. ${ }^{5}$

Pay flexibility outside of national agreements was also possible in relation to timeworkers, especially in the form of special merit awards, bonuses and lieu rates. (Overtime hours and bonuses applied to both pieceworkers and timeworkers.) But it remains highly likely - and certainly worthy of empirical investigation - that piecework offered the greater pay responsiveness to the pressures of wartime output demand together with the associated shortages of skilled labour supply.

\section{(b) Piecework and timework under tight labour market conditions}

The engineering labour market was especially tight in the years marking the runup to and the early period of war. Two arguments in the existing literature support the view that this market condition itself would give rise to a greater emphasis on piecework.

The first concerns the value of piecework in relation to the outside wage (Lazear, 1986). The better are the opportunities in outside employment, the greater are the losses incurred by the firm in failing to sort and remunerate workers by value added. So the

\footnotetext{
${ }^{5}$ A 1949 study into the problems of measuring and comparing productive performance across different engineering plants (Joint Committee of the Institute of Production Engineers and of the Institute of Cost and Works Accountants) highlighted the common practice of 'padding' engineers' estimates of the speed and effort required to complete job tasks in order to make wage earnings more attractive.
} 
value of piecework would rise relative to timework. Extreme labour shortages of skilled labour in the late 1930s/early 1940s - especially in the British Midlands - produced intense competition among engineering companies in respect of their demands for key workers.

"In any district firms could attract labour from other factories by adjustments in piece rates, the offer of merit bonuses or of overtime. As skilled labour grew scarcer and the number of new factories increased, poaching became steadily worse......Firms spent hundreds of pounds advertising for skilled workers while those already in their employment sometimes left as fast as new men were recruited. Labour costs increased out of all proportion to increases in output; indeed long hours, high labour turnover and high piece rates tended to bring individual output down” (Inman, 1957, p.26).

In other words, the value of the alternative wage grew relative to the value of output in the current firm. Therefore, firms perceived the advantage of offsetting higher job quit probabilities among their most productive workers by directly rewarding individual value added.

The second argument is also related to outside opportunities, but this time in relation to worker motivation and incentives. In the face of exceptional demand pressures, the employer is especially keen to motivate the workforce to provide commitment and effort on the job. But the effectiveness of the sanctions available in the case of timeworkers is inversely related to the degree of labour market tightness. Threat of dismissal in the event of shirking, for example, has potentially little impact if the worker has many alternative job opportunities. Under these circumstances, Macleod and 
Malcomson (1989) show that the employer will tend to switch to piecework contracts as a means of worker motivation. ${ }^{6}$

(c) Ability, labour heterogeneity and pay differentials

Why in general is there a positive gap between the hourly pay of pieceworkers and timeworkers, ceteris paribus? Why might the gap be expected to widen during the war period?

One major reason for the wage gap is that time working firms employ workers of lower average ability (Lazear, 1986; Brown, 1990). Suppose that there is a zero-profit equilibrium and that information is asymmetric in that workers are better informed than firms about their output potential. ${ }^{7}$ For wide enough disparities in ability and given positive monitoring costs, it may be worthwhile economically for low ability workers to match with firms that do not incur those costs. (The wage of a low ability pieceworker would not only reflect productive performance but also the cost of monitoring that performance.) Such firms pay time rates and these rates would reflect the propensity to attract workers of relatively low ability.

Why might the gap be expected to widen as the war progressed? Following Lazear (1986), suppose managers and workers have a symmetric lack of knowledge

\footnotetext{
${ }^{6}$ Another situation in which a threat of dismissal would lose its potency is when a worker nears the age of retirement. Gibbons and Murphy (1992) use the argument to explain the growing importance of incentive contracts towards the end of the careers of chief executive officers.

${ }^{7}$ The work of Lazear (1986) and Brown (1990) compare piece rates and salaries. The latter imply that perperiod earnings are fixed. This is tantamount in the present context to assuming that time-rated engineers worked fixed length workdays or weeks. Since, as is shown below, weekly hours of engineering workers changed greatly over this period the results reported in this Section are strictly first-approximations to expected outcomes. The earlier work also distinguishes between variations in individual ablility for given effort and variations in effort for given ability. Theoretical outcomes are comparable in most cases. Fama (1991) presents an interesting discussion of the distinction between hourly wages (as experienced by timerated manual engineers) and salaries. It is argued that time payoffs (e.g. hourly wages) require information about hourly effort and/or output while salary payoffs occur when there is a lack of knowledge of effort and output flows.
} 
concerning individual ability. In the short run, time rates are independent of output. Therefore, timeworkers incur no monitoring costs in contrast to pieceworkers. ${ }^{8}$ But, unlike piecework, timework involves costs arising from a failure to sort workers by individual value-added. If costs associated with labour heterogeneity rise relative to costs of monitoring performance then the value of piecework relative to timework is enhanced.

As reported in Section 2, labour heterogeneity increased as a direct result of deskilling in the industry. The identification of more narrowly defined sets of job tasks allowed companies, after providing relatively short periods of training, to upgrade semiskilled workers to undertake previously defined skilled work. The substitution of male by female workers was an important element of this latter process (Hart, 2004). The general consequence was to introduce more heterogeneous ability levels in the manufacture of specific engineering products. As a consequence, there would have been a rise in the implicit costs of failing adequately to sort workers by their contribution to output. ${ }^{9}$ In other words, the process of deskilling served to increase the relative returns to operating piece-rated payments systems.

The U.S. empirical investigation of Brown (1990) supports this line of reasoning. Based on the Industry Wage Survey of the Bureau of Labor Statistics, it is found (p.180S) that "there is less use of incentive pay (and greater use of standard rates) in jobs with

\footnotetext{
${ }^{8}$ There is an important distinction to be made here, however. A piece rate system necessitates the allocation of more resources geared to inspecting the quality of output. Time rated work, however, generally associates with high costs of supervision in order to minmise shirking (Pencavel, 1977). Monitoring costs in the main text refer to the first of these two costs.

${ }^{9}$ The problem of widening employee ability was formally recognized in employer-union agreements in relation to wage differentials between males and substitute female 'dilutees' (Inman, 1957, pp. 57-60 ). After a period of training, equal pay for equal work was the underlying principle. In practice, agreements allowed male-female wage differentials to persist where it was deemed necessary to provide female workers with extra long-term assistance and supervision. It should be added that these latter conditions were difficult to interpret and proved to be quite contentious.
} 
diverse duties than in jobs with unchanging duties repetitively performed”. The process of deskilling - aided and abetted by an increased use of automated machines - tilted the balance far more towards job tasks involving repetitive work activities. ${ }^{10}$

Not only did deskilling in the industry increase the worth of measuring and rewarding individual outputs but it also served potentially to enhance the productivity of pieceworkers since it enabled the firm to improve performance monitoring within the simplified job tasks. ${ }^{11}$ To the extent that productivity effects were reflected in pay then wage differentials of pieceworkers and timeworkers would be expected to be directly linked to labour heterogeneity.

\section{(d) Noisy output}

Several of the foregoing arguments point firmly to an expected substitution of piecework for timework during war activity. There is an offsetting argument, however. As discussed by Pencavel (1977) and Lazear (1986), a piece rate system may be disadvantaged if there is a constant need to undertake frequent revisions of piece rates and job-execution times. As stated by Lazear (p.411): "Piece rates are less likely to be chosen when the estimate of [output] is noisy”. Time rates avoid the costs of assessing and undertaking relative rapid price changes across an individual's range of job tasks. Knowles and Robertson (1951b) use the term, 'tight' piece rates, to describe long periods of product price stability in which 'equilibrium’ piece rates can be determined and administered. By contrast, these authors argue that 'loose' piece rates prevailed in

\footnotetext{
${ }^{10}$ See Cowling (2001) for reported research into the positive associations between payments by results and repetitive jobs and negative associations between payments by results and jobs with a wide range of tasks.

${ }^{11}$ For empirical evidence on a positive relationship between payments by results and labour productivity see Heywood, Siebert and Wei (1997).
} 
wartime engineering because rapid price fluctuations brought about by war demand pressures (see Figure 7 below) precluded full assessments of appropriate relative prices.

\section{Summary}

The above discussion leads to the following testable propositions.

(i) The facts that piece rates were harder to control than time rates, improved monitoring due to deskilling enhanced employers' abilities to influence productive effort, and unfamiliarity with wartime demand allowed greater freedom over piece rate setting lead to the expectation that earnings of pieceworkers were more responsive to market conditions.

(ii) On the basis of three main arguments - concerning labour scarcity and potential quit threats, incentive compatible pay in tight markets, and improved monitoring due to deskilling - we would expect the proportion of pieceworkers relative to total workers to increase during the war period. However, a fourth argument linked to noisy output serves to offset this tendency.

(iii) In line with most other studies, and not necessarily related to war activities per se, we would expect a positve gap between the pay of pieceworkers and timeworkers due to differential abilities.

(iv) To the extent that piece rate - time rate differentials reflect relative productivity we would expect a wartime widening in the differentials linked to greater labour heterogeneity.

These arguments omit one additional important variable that affected both employment and pay - viz. average weekly hours of pieceworkers and timeworkers. For 
example, would the expected relative growth of numbers of pieceworkers be accompanied by a relative growth in pieceworkers’ relative weekly hours? How did hours combine with wage rates and piece rates to influence earnings differentials? The associated role of working time is also investigated in what follows.

\section{Relative wage responsiveness to market conditions}

As noted in Section 3(a), the adoption of piece rate systems may have been attractive to employers if piecework earnings offered relatively greater pay flexibility. Wage responsiveness in certain engineering sections and geographical districts was especially important given that it was necessary to establish significant short term wage differentials in order to allow companies to overcome exceptional labour shortages.

Some insights into the relative demand elasticities of piece rates and time rates can be obtained from two sets of data. The first covers the re-armament years from 1935 to 1938 and is based on males in 15 engineering occupations ${ }^{12}$ and twenty geographical districts. $^{13}$ The second involves a single occupation group, skilled male fitters, and covers the longer period, 1926 - 1938. For both data sets, the 1938 end-date is conditioned by the availablity of district-level unemployment rates that match EEF geographical districts (obtained from Hart and Mackay, 1975). Also, I concentrate on real basic wage rates so as to avoid complications linked to differential overtime working.

I adopt the wage curve specification of Card (1995) and concentrate on

pieceworkers' real standard hourly wage, $w^{P}$, in respect of the first data set to illustrate

\footnotetext{
12 These are coppersmiths, fitters (other than skilled), fitters (skilled), toolroom fitters, labourers, machinemen (rates at or above fitter's rate), machinemen (below fitter's rate), machine moulders (at or above moulder's rate), machine moulders (below moulder's rate), moulding machine operators, moulders (loose pattern), patternmakers, platers/riveters/caulkers, sheet metal workers, and turners.

13 Aberdeen, Barrow, Bedfordshire, Birmingham, Bolton, Burnley, Coventry, Derby, Dundee, Halifax, Leicester, Lincoln, Liverpool, London, Manchester, North East Coast, Preston, Rochdale, Sheffield, Wigan.
} 
the methodology. ${ }^{14}$ Averaging over all pieceworkers by occupation $i$ in district $r$ at year $t$, the underlying wage specification is given by

(3) $\log w_{i r t}^{P}=a u_{r t}+d_{r}+f_{t}+e_{i r t}$

where $u_{r t}$ is the district unemployment rate, $a$ is a constant and where $d_{r}$ and $f_{t}$ are district and time intercepts. First differencing (3) removes district fixed effects, giving

(4) $\Delta \log w_{i r t}^{P}=a_{1} u_{r t}+a_{2} u_{r t-1}+g_{t}+\Delta e_{i r t}$

where $g_{t}$ represents the reformulated time intercepts after differencing. If in (4) $a_{1}$ is found to be significantly negative and $a_{2}$ insignificant then this provides empirical support for the Phillips curve. Alternatively, if estimates of $a_{1}$ and $a_{2}$ display equal sized parameters with opposite signs then a wage curve is accepted.

The district unemployment rate in (4) does not differentiate between occupation groups. Within a given district different groups may share common components of variance that are not captured by a single rate. This may serve to bias downwards the estimated unemployment standard errors (Moulton, 1986). In order to tackle this problem, I extend the two-step estimation approach of Solon et al. (1994) to include cross-section unemployment variation. Step 1 consists of estimating the equation (5) $\Delta \log w_{i r t}^{P}=\sum_{t=1}^{T} \sum_{r=1}^{R} \phi_{r t} D U M_{r t}+u_{i r t}$

\footnotetext{
${ }^{14}$ EEF data allow us to obtain estimates of weekly pay in (2) based on a standard workweek (i.e. excluding overtime hours). Hourly standard pay, $w^{P}$, is then obtained by dividing this weekly total by 47 , the length of weekly standard hours that applied to all workers in the industry.
} 
where, summing over all $T$ time periods and $R$ districts, $D U M_{r t}$ denotes a dummy variable that takes the value of 1 for district $r$ at year $t$. In step 2, estimates of $\phi_{r t}$ in (3) are regressed on unemployment rates plus district and time intercepts, that is

(6) $\hat{\phi}_{r t}=b_{1} u_{r t}+b_{2} u_{r t-1}+d_{r}+f_{t}+v_{r t}$.

This two step estimation procedure is also carried out separately with respect to timeworkers' (log) real wages, $\log w^{T}$.

For the second data set, based on a single-occupation, only equation (4) is estimated.

\section{Table 1 here}

Ordinary Least Squares estimates are reported in Table 1. For both sets of results, a significant coefficient on the change of unemployment is obtained only in the pieceworkers' equations. A one-point decrease in the rate of unemployment is associated with a 0.49 percent increase in the real standard hourly wage in the 1935-38 time series estimated over 15 occupations and a 0.35 percent increase in the 1926-38 series for a single occupation. Separating current and lagged unemployment produces support for a wage curve specification in the latter regression while the two rates are insignificant at the 5 percent level in the former. While the estimated piece rate elasticities are relatively modest, the contrast markedly with the time rate equivalents. Both sets of results for timeworkers do not support an association between changes in real basic hourly wages and unemployment rates. 
The comparative findings in Table 1 are in line with work on more recent U.S. data by Devereux (2001). This emphasises the need to discriminate among types of payment methods in the study of wage cyclicality. Compared to earlier micro longitudinal studies, but ones that have not conducted wage disaggregation, Devereux finds relatively weak cyclicality. A marked exception is the finding of strong wage procyclicality among workers receiving incentive-based pay. The latter comprise a residual group in the Panel Study of Income Dynamics, comprising individuals compensated by "piece rates, commissions, tips, and in other ways".

These results are consistent with the view that the engineering industry adjusted piecework payments directly in response to economic demand pressures, as represented by changes in district-level unemployment rates. By contrast, basic time rates were significantly less sensitive to market conditions.

\section{Relative piecework/timework employment and hours growth}

\section{Employment}

From a long-term perspective, it is clear that the war years marked a switch towards a greater employment of piecework among existing skilled occupations. In 1931, 56 percent of skilled engineers were paid piece rates and this rose to 70 percent in 1942 before falling back to 61 percent in 1948 (Knowles and Hill, 1951b). But job growth during the war involved predominantly semi-skilled female labour. Over 80 percent of wartime semi-skilled jobs involved piecework (Knowles and Hill, 1951b - see also Hart, for detailed female piecework/timework breakdowns by section and by females undertaking men's and women's work).

\section{Table 2 here}


What does a more disaggregated picture reveal? The incidence and growth of piecework and timework between 1935 and 1942 in fifteen engineering sections covering the main areas of wartime activity - are shown in Table 2. In twelve of the sections, positive growth in the proportions of pieceworkers to timeworkers occurred between 1935 and 1942. Of the twelve, three sections - construction engineering, locomotive manufacture and sheet metal working - displayed especially steep growths in the proportions of pieceworkers during the early war years. Extending the period from 1935 to 1951, only eight sections achieved a positive growth in the proportions of pieceworkers. Certainly in construction engineering, general engineering (heavy and light), locomotive manufacture, sheet metal working and vehicle building major relative growth was decidedly a war-related phenomenon. By contrast, in aircraft and car manufacture, sizeable reductions in the incidence of pieceworking occurred during the war affected years. Note, however, that both of these sections displayed well above average proportions of pieceworkers over the entire period.

As suggested in Section 3, deskilling and the growth of piecework went hand in hand. Sheet metal working provides an especially well documented example. ${ }^{15}$ Strong piecework growth in this section ${ }^{16}$ occurred for three principal reasons. First, technical change facilitated deskilling. Skilled manual processes in sheet metal working, involving hand and bench tools, had been increasingly replaced by power presses and automatic

\footnotetext{
${ }^{15}$ Sheet metal working was a vital war-related production activity, with essential applications in aircraft, vehicle and ship building. It concerns the engineering of thinner varieties of metal plate. A sheet metal worker cuts out, bends, and beats metal into shape (panel beating) and also laps, rivets and solders joints. Deskilling in sheet metal work in the early war years involved protracted collective bargaining discussions involving unions, employers and government (see Inman, 1957, pp. 60/1).

${ }^{16}$ The proportion of pieceworkers in sheet metal working climbed from 11 percent of total employment in 1938 to 60 percent in 1942.
} 
tools. The latter could be operated by less skilled labour. Even where traditional skilled work was retained - for example, in the use of free hand methods in the shaping of metal - associated operations (like drilling and riveting) could be carried out by semi-skilled workers. Those engaged in pressing, drilling and riveting performed relatively narrow and repetitive tasks that were suited to piece rated systems. Second, the greater labour heterogeity linked to deskilling increased the worth of measuring and rewarding individual value added. Third, sheet metal working was especially important in aircraft manufacture, centred in the Midlands. There were extremely high labour shortages in this region. Piece rates had to be settled on a job by job basis. High demand, rapid technical change and process diversity combined to drive up piece rates to very high levels and this helped employers to retain their most productive workers as well as encouraging mobility from outside industries (see Section 7).

\section{Hours}

What about labour expansion on firms' intensive margins, as represented by average weekly hours of work? As would be expected, average weekly hours grew dramatically during the early part of the war. The standard workweek in engineering between 1919 and 1946 was 47 hours. The year of peak industrial activity was 1940. Average hours in sheet metal working, aircraft manufacture, heavy general engineering and marine engineering - all vital wartime engineering sections - was 59 hours in 1940, representing 12 hours of average weekly overtime. ${ }^{17}$ A representative pattern of weekly hours between 1935 and 1942 is shown in Figure 3 for three occupations of piece rated

\footnotetext{
${ }^{17}$ Contrasting with average weekly hours of between 44 and 46 in 1931, the depth of the Great Depression.
} 
workers $(p / r)$ and time rated workers $(t / w)$ averaged across sections. Again, the peak year is 1940, with skilled machinemen averaging 60 hours per week.

What happened to the hours' growth of pieceworkers relative to timeworkers? The following regression was undertaken with respect to occupation i in engineering section $\mathrm{s}$ at time $\mathrm{t}$

$$
\log h_{i s t}^{P}-\log h_{i s t}^{T}=d_{i}+d_{s}+d_{t}+e_{i s t}
$$

where $h^{P}\left(h^{T}\right)$ is the weekly hours of pieceworkers (timeworkers), $\mathrm{d}_{\mathrm{i}}$ are occupational intercepts, $\mathrm{d}_{\mathrm{s}}$ are section intercepts, $d_{t}$ are time intercepts and $e_{i s t}$ is an error term. There are seven occupation groups ${ }^{18}$, twenty seven sections ${ }^{19}$, and seven years (from 1935 to $\left.1941^{20}\right)$

\section{Figure 3 and 4 here}

Estimation of equation (7) is based on 840 observations. A variant of (7) was also estimated for single key occupations. For each selected occupation, the dependent variable in (7) was regressed on engineering sections and time dummies. Figure 4 plots the estimated time dummies from ( $\hat{d}_{t}$ ) from the total regression of equation (7) together with the time dummies of the four selected occupations. In general, the results clearly

\footnotetext{
${ }^{18}$ Skilled fitters, labourers, machinemen (rated at or above fitter's rate), machinemen (rated below fitter's rate), moulders (loose pattern), platers/riveters/caulkers, sheet metal workers.

${ }^{19}$ Agricultural engineers, aircraft manufacturers, allied trades, boilermakers, brassfounders, construction engineers, coppersmiths, electrical engineers, founders, gas meter makers, general engineers (heavy), general engineers (light), instrument makers, lamp manufacturers, lift manufacturers, locomotive manufacturers, machine tool makers, marine engineers, motors (cars, cycles etc.), motors (commercial), scale/beam etc. makers, sheet metal workers, tank and gasholder makers, telephone manufacturers, textile machinery makers, vehicle builders, miscellaneous.

20 The year 1942 is omitted because available data are far less comprehensive for that year.
} 
indicate that the hours of pieceworkers rose relative to timeworkers, especially during the frenetic production period from 1938 to 1940.

\section{Wage differentials, relative earnings growth, and labour heterogeneity Wage differentials}

In common with general findings in the literature, the wages of pieceworkers exceed timeworkers in our data. Based on 15 engineering sections and covering the most important wartime engineering activities, Table 3 shows that between 1935 and 1942, the sectional wage differentials varied between 12 and 30 percent. Additionally, the table reveals that for ten of these sections, the early war years marked a rise in the differential compared to the period as a whole. The increase is substantial (in excess of 25 percent) in agricultural engineering, sheet metal working and vehicle building.

A critical consideration in the analysis of real wages is the steep price inflation that occurred between 1938 and 1940. From Figure 5, it can be seen that the annual rate

of change of final output prices increased more than 7- fold during these two years. Both pieceworkers' and timeworkers' real hourly wage rates fell during this period, as illustrated for selected occupations (averaged across sections) in Figure 6. However, given steep contemporaneous rises in weekly hours (see Figure 3), there were net increases in real weekly earnings (i.e. real hourly rates times average weekly hours) as revealed in Figure 7. Note also that, consistent with Table 3, wage rates and earnings of pieceworkers were above respective wages of timeworkers.

\section{Figures 5, 6 and 7 here}


I now consider piecework-timework wage differentials in more detail. Replacing hours as dependent variable in equation (7) with $\log w_{i s t}^{P}-\log w_{i s t}^{T}$ and estimating with the same occupations and sections produces the results shown in Figure 8. At the outset of war in 1939 there was a clear widening of the piece rate/time rate differentials from the sectoral estimates. The gap was especially pronounced in sheet metal working.

\section{Figure 8 here}

Wages and hours

Further insights into the relative roles of wage rates and hours can be obtained by taking advantage of the relatively simple rules relating to standard weekly hours and overtime pay that prevailed in the industry. The standard workweek was 47 hours while overtime was remunerated at 1.5 times the standard hourly rate. Illustrating for timeworkers, weekly earnings $y^{T}$ involved two variables and two constants, and may be expressed

(8) $\quad y^{T}=w^{T} \cdot Z^{T}$

where $Z^{T}=47+\max \left\{\left(h^{T}-47\right), 0\right\} \times 1.5$.

Differentiating with respect to time gives

(9) $\frac{d y^{T}}{d t}=\frac{d w^{T}}{d t} Z^{T}+\frac{d Z^{T}}{d t} w^{T}$. 
The rules with respect to maximum standard hours and overtime premium pay also applied to pieceworkers and so the same decomposition can be carried out with respect to pieceworkers' earnings $\left(y^{P}\right)$, hourly wages $\left(w^{P}\right)$, and hours $\left(Z^{P}\right)$.

For given maximum standard weekly hours and overtime premium, weekly earnings can increase for two reasons. First a rise in the standard rate increases both standard earnings and overtime earnings. Second, a rise in weekly hours above 47 leaves standard earnings constant but increases overtime earnings. Defining wages and hours expressions at the mid point of the time interval 1938 -1941, Table 4 contains values of the expressions in (9) (given as percentages) for six highly strategic sections of engineering. In all sections and under both payments' methods, average weekly real earnings grew (i.e. $d y^{P} / d t>0$ and $d y^{T} / d t>0$ ), although only in aircraft manufacture (pieceworkers and timeworkers) and general engineering (timeworkers) were the growth rates substantial. Note, however, that increases derived mainly from changes in hours, i.e. $d Z^{P} / d t>0$ and $d Z^{T} / d t>0$ : in most cases real wage rates fell (i.e. $d w^{P} / d t<0$ and $d w^{T} / d t<0$ - see also Figure 7).

\section{Table 4 here}

Wage differententials and labour heterogeneity

Deskilling and the related increase in labour heterogeneity would be expected to lead to an increase in the relative productivity of pieceworkers since it facilitated an improved ability both to systematize and to monitor productive performance. It is possible to test this proposition using the added inference that relative productivity gains would be reflected in piecework-timework wage differentials. 
I am able to obtain two measures of labour heterogeneity. The first, and undoubtedly one of the best measures for the period, is the proportion of women to total engineering workers. These data are available at a sectional level of aggregation. To conform, wage data for four male occupation groups (see Table 5) were aggregated to sectional level. Women were not well represented in all engineering sections and I confine attention to sections that, based on the four occupations, employed at least 500 women (and at least 500 men) in each and every period from 1935 to 1942 . This provided eight sections in total. ${ }^{21}$ The second measure relates to one occupational group, male fitters. Here, for the period 1934 to 1939, I can obtain the proportion of non-skilled fitters to total fitters. Rearmament commenced in 1935 and issues of skill shortages, deskilling and greater heterogeneity were also relevant - especially among male workers - in this earlier period. I considered those sections with at least 500 skilled fitters and at least 500 unskilled fitters in each and every year, giving four sections in total.

For section s at time t, I estimated the following equation for male pieceworktimework wage differentials

(8) $\log w_{s t}^{P}-\log w_{s t}^{T}=b I_{s t}+d_{s}+d_{t}+e_{s t}$

where $I$ is the index of labour heterogeneity.

Results are shown in Table 5. Both sets of results - i.e. with respect to four occupational categories in eight sections and fitters in four sections - support the hypothesis that increased labour heterogeneity was positively associated with the wage

\footnotetext{
${ }^{21}$ The sections are reported in Table 5. Four of these - aircraft manufacture, electrical engineering, heavy general engineering and light general engineering - are sections with high proportions of 'women doing men’s work' between 1940 and 1942 (see Hart, 2004, Table 1).
} 
differentials. The strength of these associations are underlined by the fact that the two heterogeneity measures are significant despite the inclusion of time dummies that serve to take out trend and other systematic time effects.

\section{District disaggregation: the importance of the British Midlands}

The pressures on the engineering industry during the war-affected years were by no means evenly spread across geographical districts. Before the re-armament period, some districts had developed engineering and related industries that were to prove essential to war needs. Leading in this respect was the British Midlands - with its manufacturing epicentre in Coventy. During the decades preceeding the war, this region had developed light engineering, vehicle construction and aircraft manufacturing sections. These activities were essential to war production and, unsurprisingly, related wartime production - and especially munitions supply - naturally developed alongside. High earnings attracted significant numbers of immigrant workers from other regions and new factories were constructed that were geared directly to war provision (Shenfield and Sargant Florence, 1944-45). Intense inter-firm competition to attract scarce skilled labour drove up Midlands' wages well above the average of other areas. Under these circumstances, and following the aguments in Section 3(b), piece rates offered the best means of retaining the most productive workers. In fact, there was particularly intense pressure on piece-rates in the Midlands at this time (Inman, 1957, pp. 320/1).

\section{Figures 9, 10 and 11 here}

Concentrating on skilled fitters, Figures $9-11$ illustrate the special position of Coventry relative to (a selection of) other engineering districts. Figure 9 shows that real time rates 
of pay during the 1935-1942 period were between 10 and 20 percent higher in Coventry than in London. As for piece rates, Figure 10 reveals that war pressure produced a 30 percent differential between Coventry and the next highest district by 1942, with exponential growth in rates post 1938. Additional time-series data are available for skilled fitters allowing us to see, in Figure 11, the piece rate/time rate differentials in a longer term perspective, from 1927 to 1942. The intense impact of war activity on the Coventry district is highlighted by an extreme outlying growth in the differential compared to elsewhere.

\section{Conclusions}

There are six main sets of findings pertaining to male pieceworkers and timeworkers.

(a) Piece rates exhibited significant positive demand elasticities in the rearmament years that preceeded the war in sharp contrast to time rates.

(b) Generally, the proportions of pieceworkers to total workers rose during the war in the most important wartime sections of the industry from already high levels. From both employment and wage perspectives, sheet metal working experienced the most radical shift towards piece-rated work.

(c) While the weekly hours of both timeworkers and pieceworkers grew substantially in the early war years from already historically high levels, piecework/timework hours differentials increased.

(d) The importance of hours growth, from the perspectives of both pieceworkers and timeworkers, is underlined by the fact that during the war real weekly earnings rose despite real reductions in hourly piece and time rates. 
(e) Piecework/timework wage differentials widened considerably in the early war years. The widening wage levels and differentials were especially marked in Coventry, the centre of aircraft manufacture, vehicle construction and munitions supply and the most vital engineering district in relation to war production.

(f) Widening piecework-timework wage differentials were significantly associated with increased labour heterogeneity. 


\section{References}

Brown, C. 1990. Firms' choice of method of pay. Industrial and Labor Relations Review 43 (Special Issue), 165-S - 182-S.

Card, D. 1995. The wage curve: a review. Journal of Economic Literature 33, 785-799.

Cowling, M. 1991. Fixed wages or productivity pay: evidence from 15 EU countries. Small Business Economics 16, 191-204.

Devereux, P J. 2001. The cyclicality of real wages within employer-employee matches. Industrial and Labor Relations Review 54: 835-850.

Fama, E F. 1991. Time, salary, and incentive payoffs in labor contracts. Journal of Labor Economics 9, 25-44.

Feinstein, C H., 1972, National income, expenditure and output of the United Kingdom 1855-1965, Cambridge, Cambridge University Press.

Gibbons, R and K J Murphy. 1992. Optimal incentive contracts in the presence of career concerns: theory and evidence. Journal of Political Economy 100, 468-505.

Goldin, C. 1986. Monitoring costs, occupational segregation by sex: a historical analysis. Journal of Labor Economics 4, 1-27.

Hart, R A. 2004. Women doing men's work and women doing women’s work: female work and pay in British wartime engineering. Department of Economics, University of Stirling (mimeo).

Hart, R A and D I MacKay. 1975. Engineering earnings in Britain, 1914-68, Journal of the Royal Statistical Society (Series A) 138, 32-50.

Heywood, J S, W S Seibert and X Wei. 1997. Payments by results systems: British evidence. British Journal of Industrial Relations 35, 1-22.

Inman, P. 1957. Labour in the munitions industries. London: HMSO.

Joint Committee of the Institution of Production Engineers and the Institute of Cost and Works Accountants. 1949. Interim report on meausurement of productivity.

Knowles, KG J C and T P. Hill. 1954. The structure of engineering earnings. Bulletin of the Oxford University Institute of Statistics 16, 272-328.

Knowles, K G J C and D J. Robertson. 1951a. Some notes on engineering earnings, Bulletin of the Oxford Institute of Statistics 13, 223-228. 
Knowles, K G J C and D J Robertson. 1951b. Earnings in engineering, 1926-1948. Bulletin of the Oxford Institute of Statistics 13, 179-200.

Lazear, E P. 1986. Salaries and piece rates, Journal of Business 59, 405-431.

Lazear, E P. 2001. Performance pay and productivity. American Economic Review 90, $1346-1361$.

Marsh, A. 1965. Industrial relations in engineering. London, Pergamon Press.

MacLeod, W B and J M Malcomson. 1989. Implicit contracts, incentive compatibility, and involuntary unemployment. Econometrica 57, 447-480.

Ministry of Labour and National Service. 1947. Report for the years 1939 - 1946. London: HMSO.

Moulton, B R. 1986. Random group effects and the precision of regression estimates. Journal of Econometrics 32: 385-397.

Paarsch, H J and B Shearer. 2000. Piece rates, fixed wages, and incentive effects: statistical evidence from payroll records. International Economic Review 41, 59 92.

Parker, R A C. 1981. British rearmament 1936-9: Treasury, trade unions and skilled labour. English Historical Review 96, 306-43.

Pencavel, J. 1977. Work effort, on-the-job screening, and alternative methods of remuneration, Research in Labor Economics 1, 225-258.

Shenfield, A and P Sargent Florence. 1944-1945. The economies and diseconomies of industrial concentration: the wartime experience of Coventry. Review of Economic Studies 12, 79-99.

Seiler, E. 1984. Piece rate vs. time rate: the effect of incentives on earnings, Review of Economics and Statistics 66, 363-376.

Solon, G, R Barsky, and J A. Parker. 1994. Measuring the cyclicality of real wages: how important is composition bias? Quarterly Journal of Economics 109, 1-26. 
Table 1 Effects of a change in the unemployment rate on changes in the log real hourly standard wages of pieceworkers and timeworkers

\begin{tabular}{|c|c|c|c|c|}
\hline & \multicolumn{2}{|c|}{ Fifteen occupations, 1935-1938 } & \multicolumn{2}{|c|}{ Skilled fitters, 1926-1938 } \\
\hline & Piece-rate workers & Time-rate workers & $\begin{array}{l}\text { Piece-rate } \\
\text { workers }\end{array}$ & $\begin{array}{l}\text { Time-rate } \\
\text { workers }\end{array}$ \\
\hline$\Delta \mathbf{u}_{\mathrm{rt}}$ & $\begin{array}{l}-0.49 * \\
(0.24)\end{array}$ & $\begin{array}{c}0.02 \\
(0.19)\end{array}$ & $\begin{array}{c}-0.35^{* *} \\
(0.14)\end{array}$ & $\begin{array}{l}-0.01 \\
(0.05)\end{array}$ \\
\hline $\mathbf{u}_{\mathrm{rt}}$ & $\begin{array}{l}-0.68 \\
(0.38)\end{array}$ & $\begin{array}{c}0.08 \\
(0.29)\end{array}$ & $\begin{array}{c}-0.39 * * \\
(0.19)\end{array}$ & $\begin{array}{l}-0.02 \\
(0.06)\end{array}$ \\
\hline $\mathbf{u}_{\mathrm{rt}-1}$ & $\begin{array}{c}0.41 \\
(0.22)\end{array}$ & $\begin{array}{c}0.02 \\
(0.16)\end{array}$ & $\begin{array}{l}0.33^{* *} \\
(0.14)\end{array}$ & $\begin{array}{l}0.002 \\
(0.05)\end{array}$ \\
\hline Observations & 59 & 59 & 204 & 180 \\
\hline
\end{tabular}

Notes: The first two results columns refer to the second-stage estimates of equation (6). Associated firststage estimates - i.e. equation (5) - are based on 546 observations. Estimates in the last two columns are based in equation (4). Figures in parenthesis are robust standard errors. ${ }^{* *}\left(^{*}\right)$ denote coefficients statistically significant at $0.05(0.10)$. The dependent variables are multiplied by 100 so that the estimated unemployment coefficients represent percentage changes in the real wage for a one point increase in the unemployment rate.

Table 2

Relative incidence and growth of piecework by engineering section, 1935- 1951

\begin{tabular}{|c|c|c|c|c|}
\hline Engineering section & $\begin{array}{l}\text { Mean } \\
\text { proportion of } \\
\text { pieceworkers } \\
1935-1942\end{array}$ & $\begin{array}{l}\text { Percentage } \\
\text { change in } \\
\text { proportion } \\
\text { 1935-1942 }\end{array}$ & 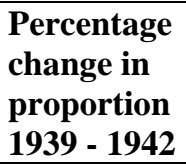 & $\begin{array}{l}\text { Percentage } \\
\text { change in } \\
\text { proportion } \\
1935-1951\end{array}$ \\
\hline Agricultural engineers & 0.61 & 7.9 & 2.9 & -11.8 \\
\hline
\end{tabular}




\begin{tabular}{|l|c|c|c|c|}
\hline Aircraft manufacturers & 0.75 & -19.9 & -10.2 & 13.2 \\
\hline Boilermakers & 0.49 & 14.8 & 9.6 & 17.8 \\
\hline Construction engineers & 0.37 & 13.7 & 43.7 & -0.5 \\
\hline Electrical engineers & 0.62 & -5.0 & -3.9 & 2.3 \\
\hline Founders & 0.35 & 36.5 & 23.3 & 34.5 \\
\hline General engineering (heavy) & 0.62 & 20.0 & 12.9 & 6.5 \\
\hline General engineering (light) & 0.49 & 22.7 & 12.3 & -5.5 \\
\hline Locomotive manufacturers & 0.65 & 5.0 & 15.7 & -3.9 \\
\hline Marine engineers & 0.37 & 23.9 & 25.2 & 55.7 \\
\hline Machine tool makers & 0.59 & 0.11 & -10.9 & 8.2 \\
\hline Motors: cars, cycles etc. & 0.78 & -14.2 & -12.2 & -8.9 \\
\hline Motors: commercial & 0.84 & 1.9 & 0.3 & -1.8 \\
\hline Sheet metal workers & 0.34 & 31.2 & 39.7 & 0.2 \\
\hline Vehicle builders & 0.70 & 18.2 & 4.7 & -22.9 \\
\hline
\end{tabular}

Table 3 Piece rate/ time rate percentage differentials by engineering section

\begin{tabular}{|l|c|c|c|}
\hline Engineering section & $\begin{array}{c}\text { Mean standard } \\
\text { hourly wage } \\
\text { differential } \\
\mathbf{1 9 3 5}-\mathbf{1 9 4 2} \\
\text { (a) }\end{array}$ & $\begin{array}{c}\text { Mean standard } \\
\text { hourly wage } \\
\text { differential } \\
\mathbf{1 9 3 9 - 1 9 4 2} \\
\text { (b) }\end{array}$ & $\begin{array}{c}\text { Percentage change } \\
\text { [(b) compared to (a)] }\end{array}$ \\
\hline Agricultural engineers & 12.9 & 17.1 & 32.6 \\
\hline Aircraft manufacturers & 15.4 & 16.7 & 8.4 \\
\hline Boilermakers & 15.2 & 15.9 & 4.6 \\
\hline Construction engineers & 16.9 & 18.6 & 10.1 \\
\hline Electrical engineers & 20.4 & 19.8 & -2.9 \\
\hline Founders & 14.9 & 16.9 & 13.4 \\
\hline General engineering (heavy) & 16.8 & 16.4 & -2.4 \\
\hline General engineering (light) & 16.6 & 16.5 & -0.6 \\
\hline Locomotive manufacturers & 17.6 & 20.2 & 14.8 \\
\hline Marine engineers & 20.5 & 20.2 & -1.5 \\
\hline Machine tool makers & 19.2 & 18.0 & -6.3 \\
\hline Motors: cars, cycles etc. & 29.1 & 32.5 & 11.7 \\
\hline Motors: commercial & 23.0 & 23.3 & 1.3 \\
\hline Sheet metal workers & 15.1 & 19.1 & 26.5 \\
\hline Vehicle builders & 12.6 & 16.8 & 33.3 \\
\hline
\end{tabular}

Table 4 Relative percentage contributions of wage rates and hours to total weekly earnings growth between 1938 and 1941

\begin{tabular}{l|lll|ll}
\hline & $d y^{P} / d t$ & $\left(d w^{P} / d t\right) Z^{P}$ & $\left(d Z^{P} / d t\right) w^{P}$ & $d y^{T} / d t$ & $\left(d w^{T} / d t\right) Z^{T} \quad\left(d Z^{T} / d t\right) w^{T}$ \\
\hline & \multicolumn{2}{|c|}{ Pieceworkers } & Timeworkers \\
\hline
\end{tabular}




\begin{tabular}{l|ccc|ccc}
\hline Aircraft manufacture & 11.4 & 3.6 & 7.8 & 9.2 & 0.6 & 8.6 \\
Electrical engineering & 1.5 & -14.4 & 16.0 & 2.2 & -9.4 & 11.7 \\
Marine engineering & 0.4 & -14.3 & 14.7 & 2.2 & -12.6 & 14.8 \\
Machine tools & 0.2 & -9.8 & 10.0 & 2.6 & -7.6 & 10.2 \\
$\begin{array}{l}\text { General engineering } \\
\text { (heavy) }\end{array}$ & 0.3 & -11.1 & 11.4 & 10.3 & -16.9 & 27.2 \\
General engineering (light) & 6.4 & -11.3 & 17.7 & 7.4 & -10.4 & 17.8 \\
\hline
\end{tabular}


Table 5 Male piecework-timework wage differentials and labour heterogeneity by engineering section (weighted OLS) ${ }^{a}$

\begin{tabular}{|c|c|c|}
\hline & $\begin{array}{c}\text { Four occupations } \\
\text { 1935-1942 }\end{array}$ & $\begin{array}{c}\text { Fitters } \\
\text { 1934-1939 }\end{array}$ \\
\hline Proportion female to total workers & $\begin{array}{c}0.24^{* *} \\
(0.1)\end{array}$ & - \\
\hline Proportion non-skilled to total fitters & - & $\begin{array}{l}1.05^{*} \\
(0.49)\end{array}$ \\
\hline Aircraft manufacture & $\begin{array}{l}0.34^{* *} \\
(0.04)\end{array}$ & - \\
\hline Allied trades ${ }^{c}$ & $\begin{array}{l}0.23 * * \\
(0.04)\end{array}$ & - \\
\hline Electrical engineering & $\begin{array}{l}0.17 * * \\
(0.03)\end{array}$ & $\begin{array}{l}0.16^{* *} \\
(0.04)\end{array}$ \\
\hline Founders & $\begin{array}{l}0.27 * * \\
(0.07)\end{array}$ & - \\
\hline General engineering (heavy) & $\begin{array}{l}0.27 * * \\
(0.08)\end{array}$ & - \\
\hline General engineering (light) & $\begin{array}{c}0.15^{* *} \\
(0.05)\end{array}$ & $\begin{array}{l}0.10^{*} \\
(0.05)\end{array}$ \\
\hline Motors, cars and cycles & $\begin{array}{l}0.27 * * \\
(0.04)\end{array}$ & $\begin{array}{c}0.05 \\
(0.05)\end{array}$ \\
\hline Number of observations & 64 & 24 \\
\hline
\end{tabular}

Notes: ${ }^{a}$ Regressions include time dummies. ${ }^{\mathrm{b}}$ Moulders (loose pattern); platers, riveters and caulkers; machinemen (above fitter's rates); machinement (below fitters rates). ${ }^{~}$ Excluded section is telephone manufacture. ${ }^{\mathrm{d}}$ Robust standard errors in brackets. ${ }^{* *}\left({ }^{*}\right)$ denote coefficients statistically significant at 0.05 (0.10). 


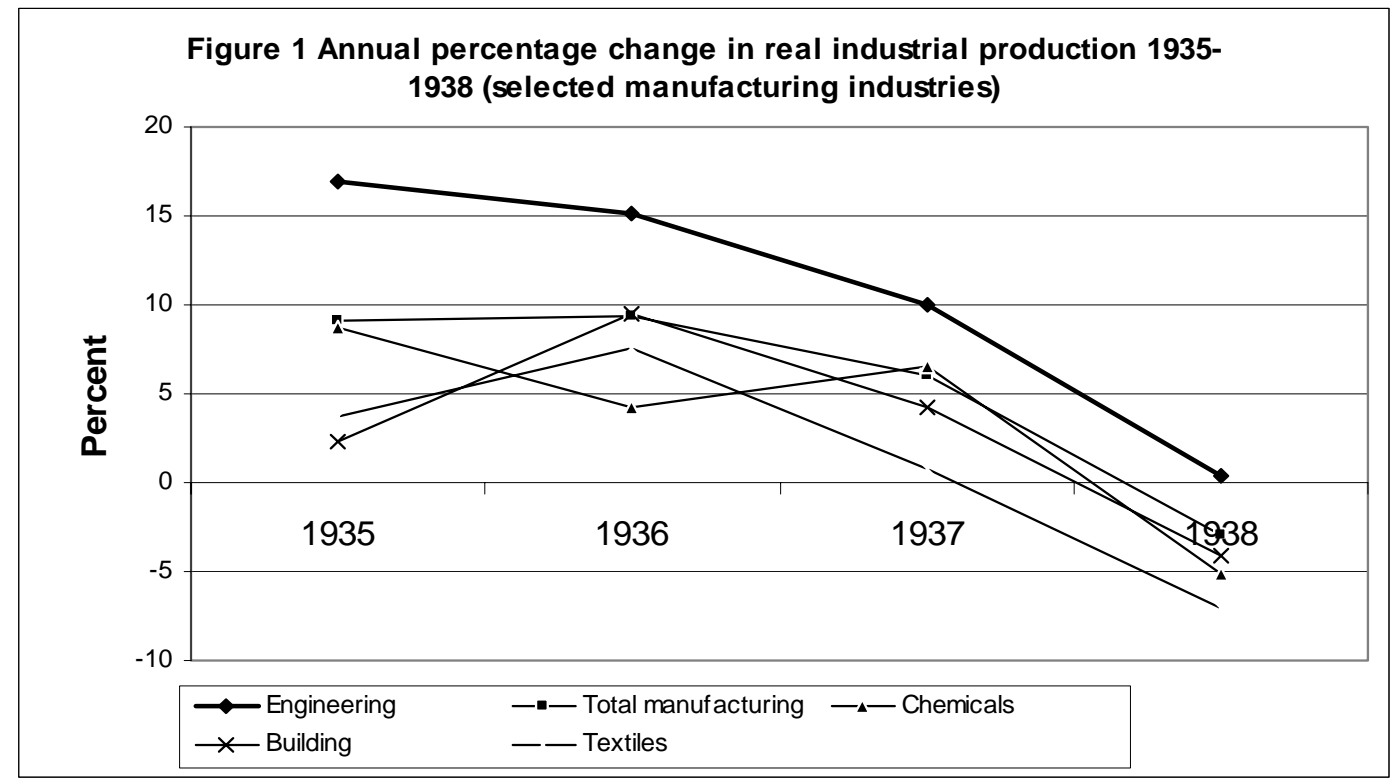

Source: Feinstein (1972)

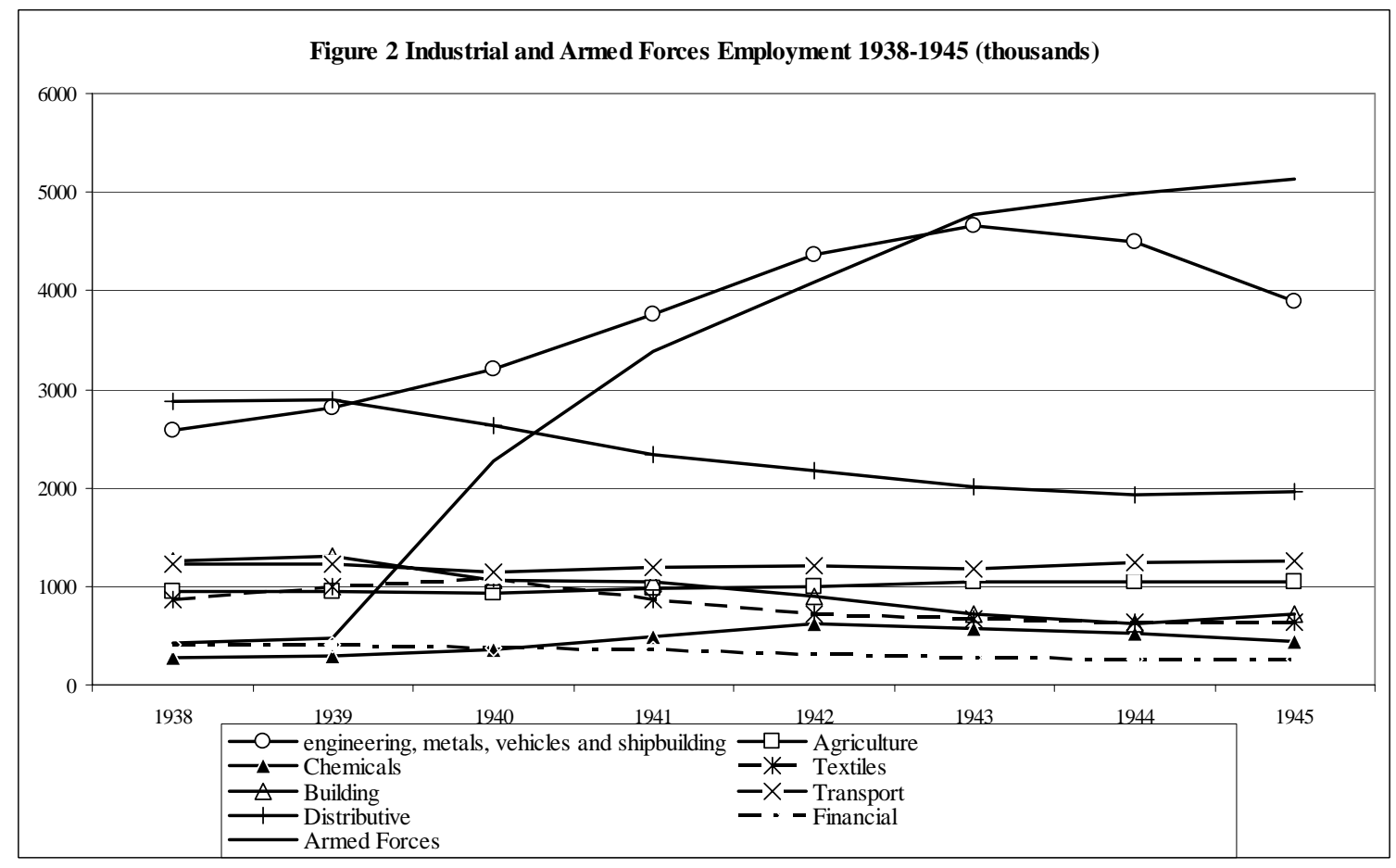




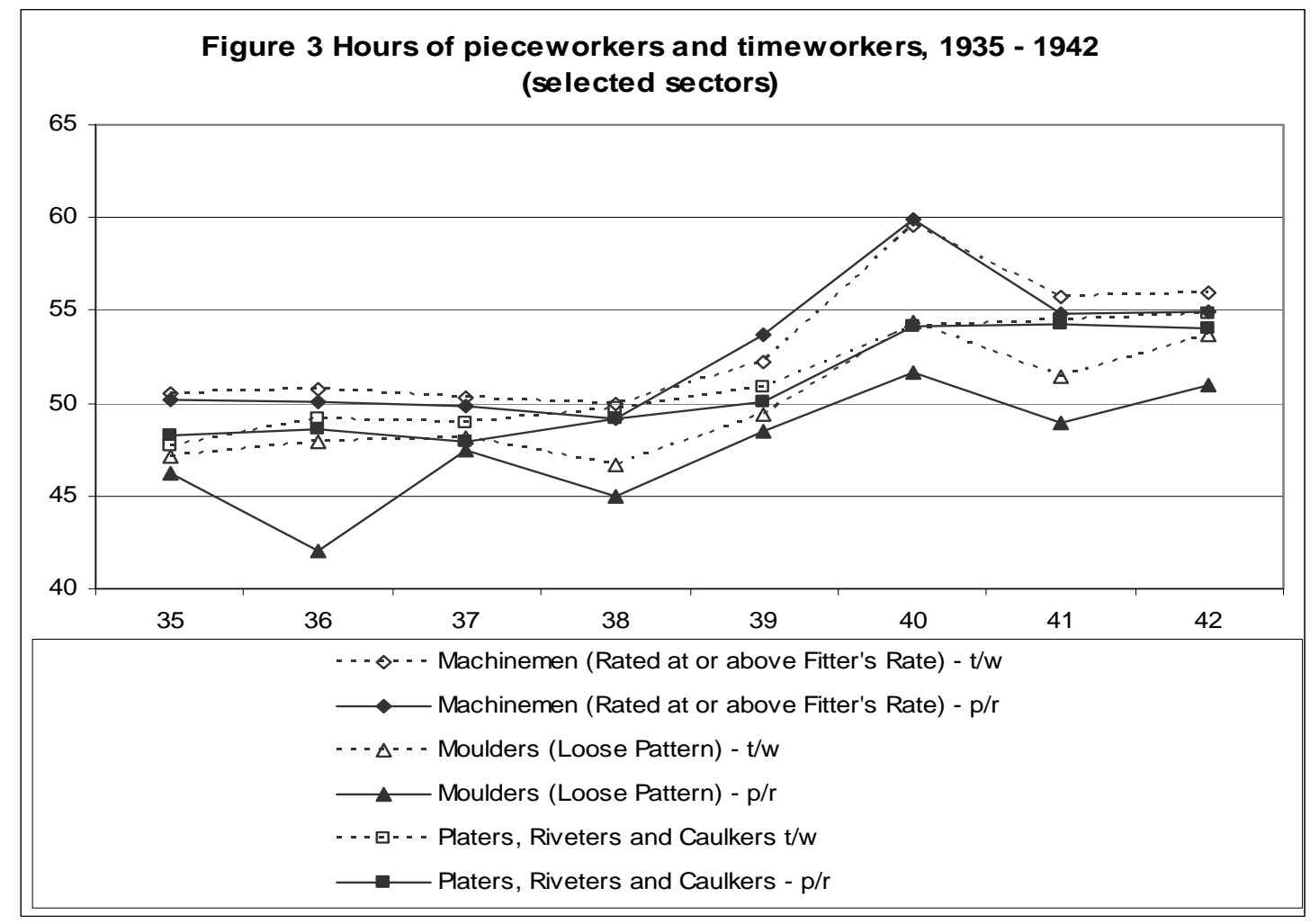

Figure 4 Piecework - timework hours differentials, 1935 - 1941

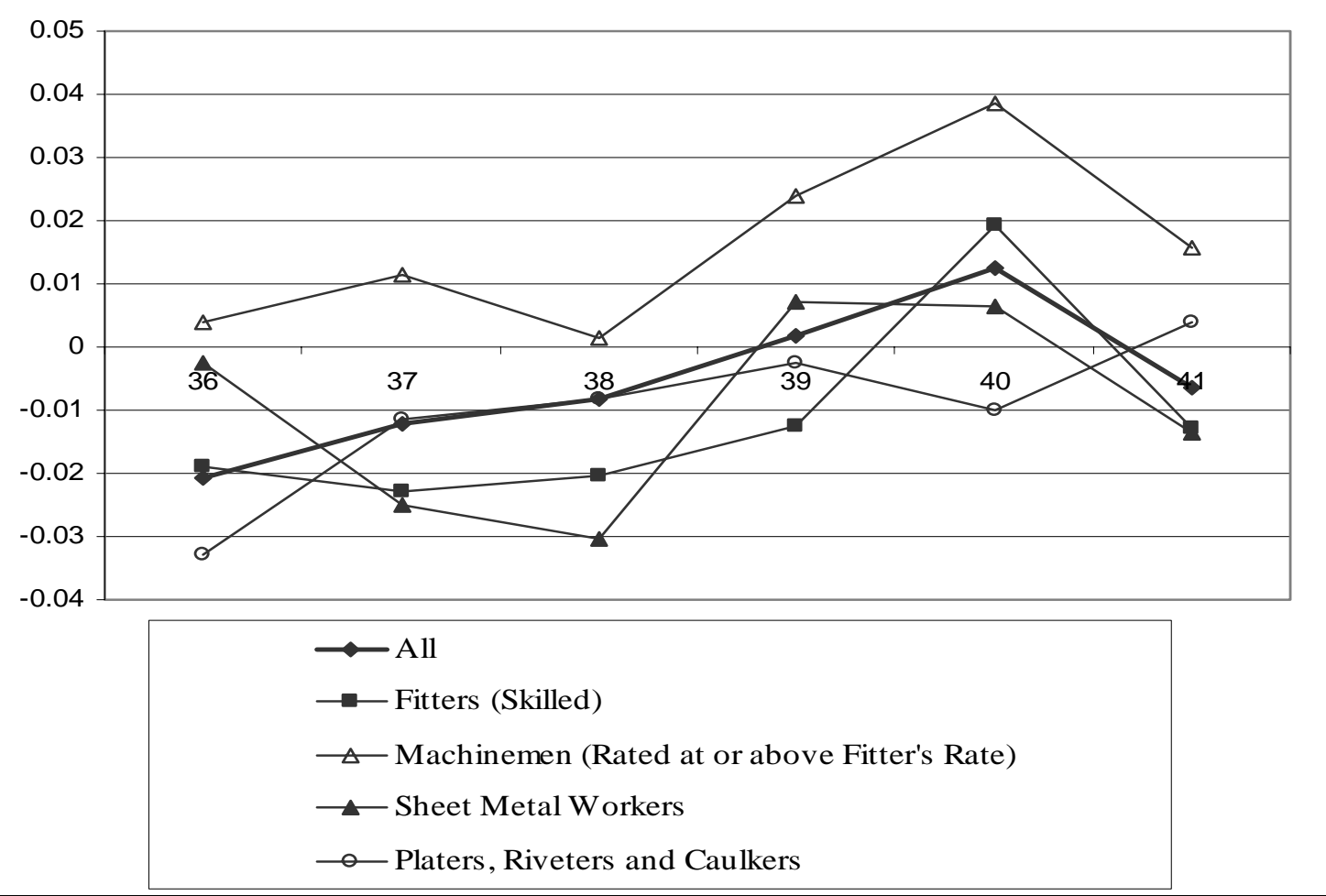



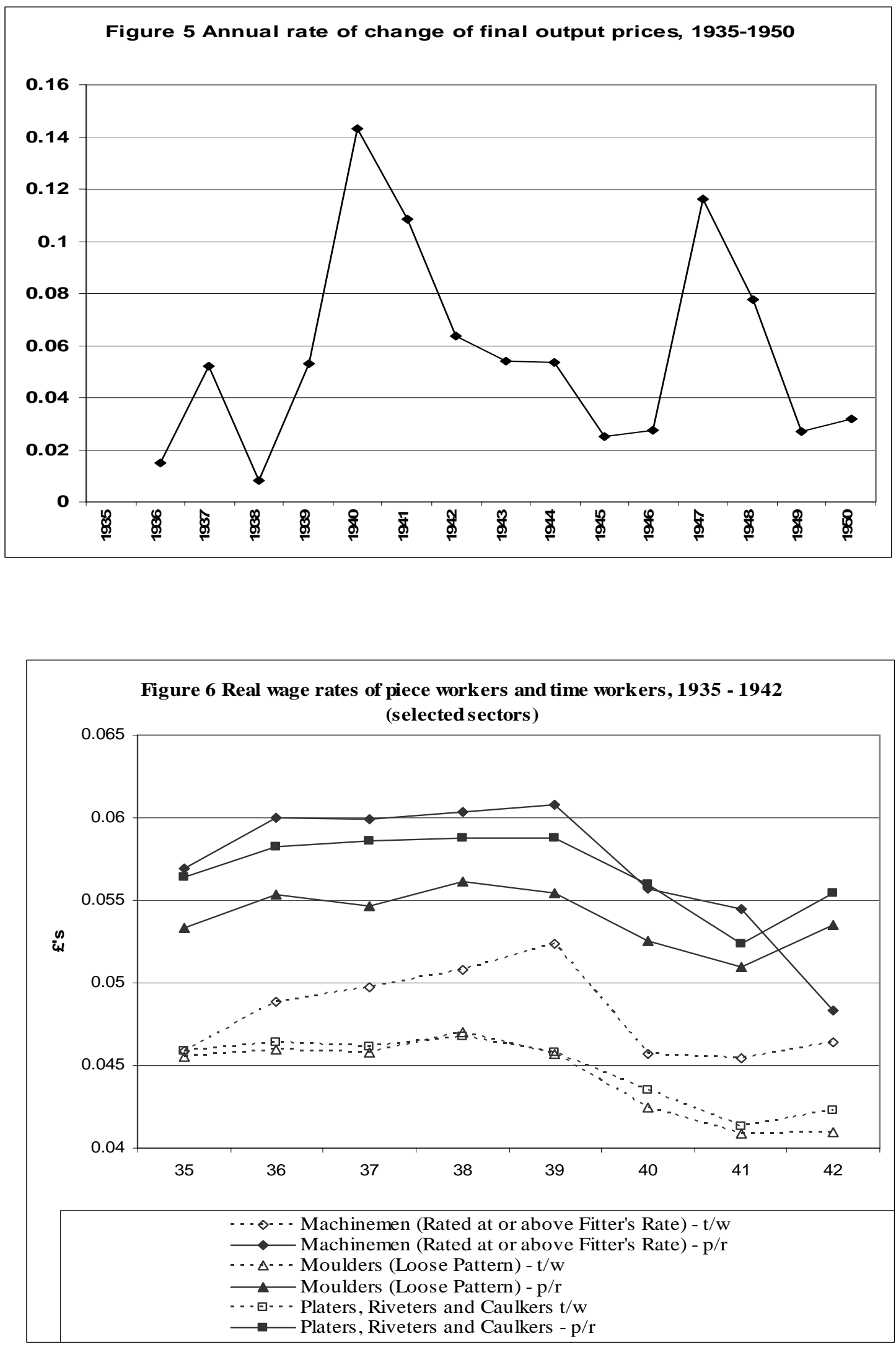

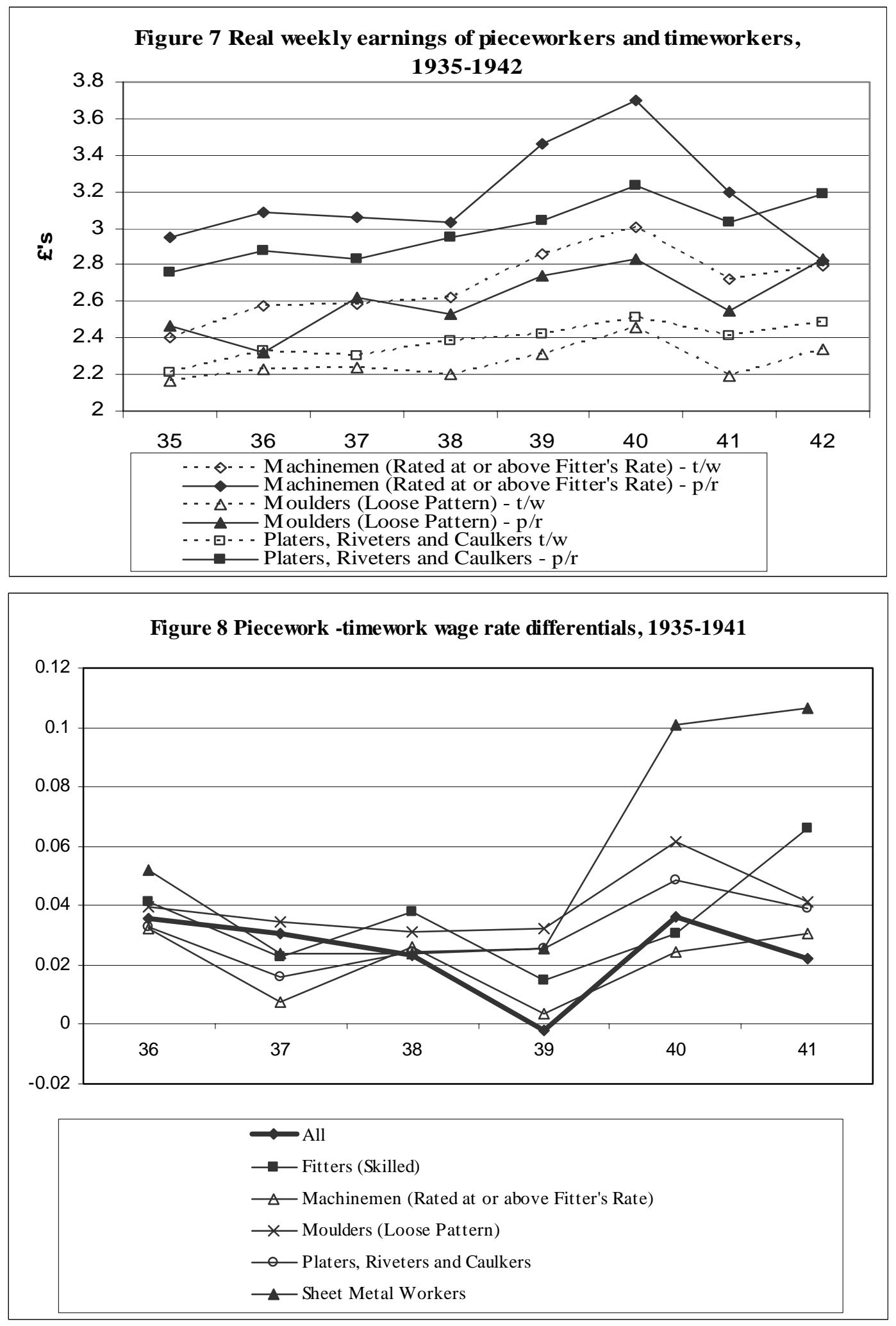

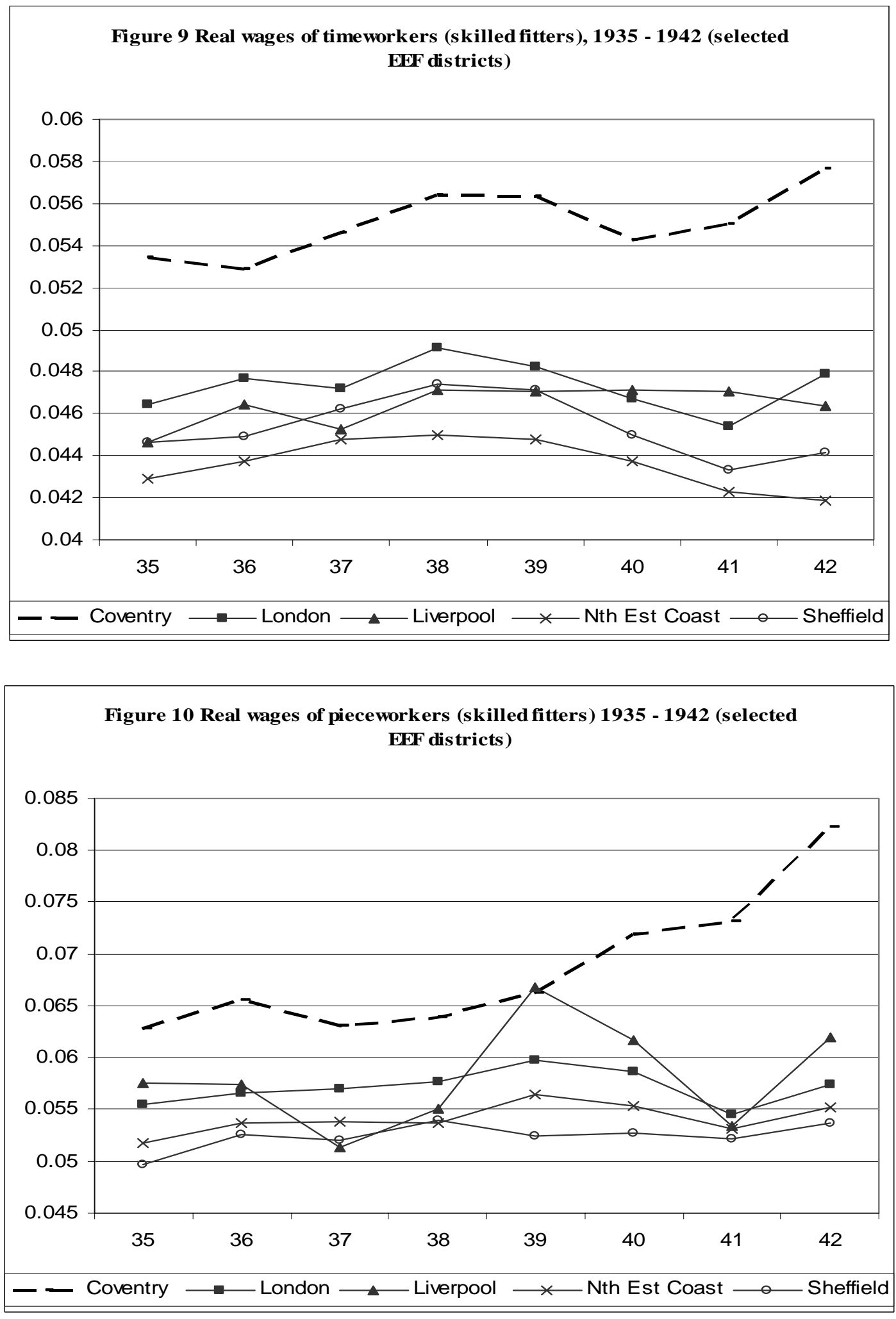


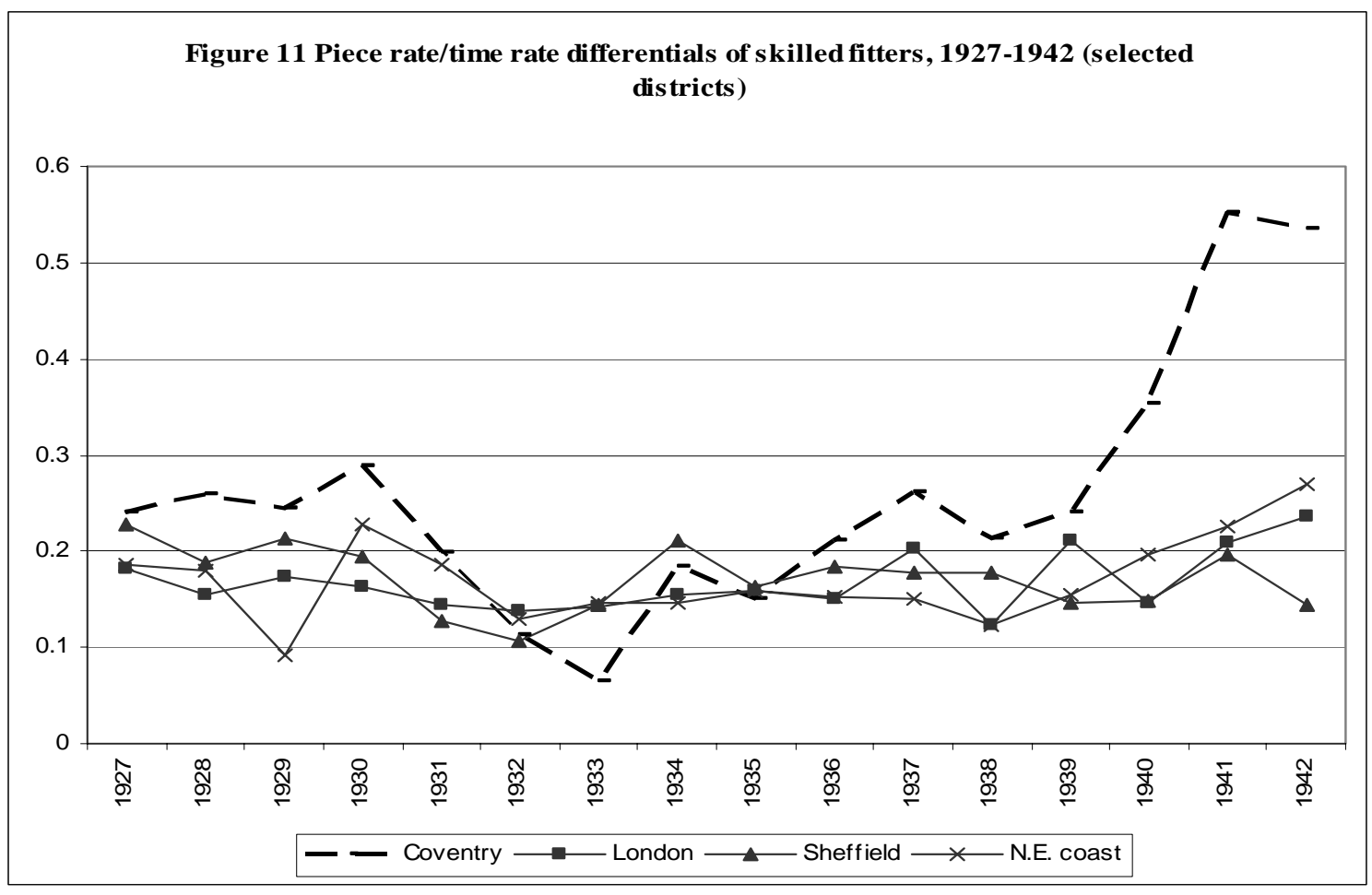

